\title{
CURRENT SITUATION AND FUTURE TRENDS IN THE CHOOSEN PROCESS FROM THE PERSPECTIVE OF SMALL AND MEDIUM- SIZED ENTERPRISES IN THE SOUTH BOHEMIAN REGION
}

\author{
Jaroslav Vrchota ${ }^{1}$, Monika Březinová ${ }^{2}$ \\ ${ }^{1}$ Jihočeská univerzita v Českých Budějovicich, Ekonomická fakulta, Studentská 13, 37300 České Budějovice \\ Email:vrchota@ef.jcu.cz \\ ${ }^{2}$ Jihočeská univerzita v Českých Budějovicich, Ekonomická fakulta, Studentská 13, 37300 České Budějovice \\ Email:brezina@ef.jcu.cz
}

\begin{abstract}
Small and medium-sized enterprises play an important role in creating working opportunity and generally act as a factor of social stability and economic development. Currently, there are several views on how to classify small and medium-sized enterprises. It depends on what classification is used for. For research purposes of GAJU 068/2010/S, the enterprises have been divided according to the number of employs. The aim of this research is to characterize the main business processes which are small and medium-sized enterprises engaged in and specify the most important indicators provided. Partial results of this research are presented in this article we focus on the current situation and trends in marketing, finance and human resources processes as seen by leaders of small and medium-sized enterprises in the South bohemian region.
\end{abstract}

Keywords: finance, human resources, marketing, processes, small and medium-sized enterprises.

JEL classification: M0

Doručeno redakci: 15.10.2012; Recenzováno: 7.2.2013; 12.2.2013; Schváleno k publikování: 16.4.2013

\section{Introduction}

Small and medium-sized enterprises play the main role by creating job opportunities and act as a factor of social stability and economic development in general. The European Union considers small and medium-sized enterprises as a backbone of European economy, employment and social integration. The Czech Republic is one of the countries in which further development of small and medium-sized enterprises has the significant impact on the whole economic and social development of the country and particular regions. (Dalíková, 2011).

Currently, there are several views on how to classify small and medium- sized enterprises (SME). It depends on what is the classification used for. The most common is this division used by providing financial aid either from the government or the EU. According to the classification of the EU, retail small and medium-sized enterprise is considered the company that employ less than 250 employees and its annual turnover does not exceed 50 million euros, or its total annual balance sheet does not exceed 43 million euros. Within the SME category, small enterprise is defined as enterprise employing less than 50 employees and its annual turnover or total annual balance sheet does not exceed 10 million euros. Retail (small) businessmen are defined as businessmen employing less than 10 people and their annual turnover or total annual balance sheet does not exceed 2 million euros. Veber agrees, that for the classification of SME number of employees is crucial, but he also recommends other indicators (Veber, 2003). According to the number of employees, there are others divisions: micro (1-10 employees), small business (11-50 employees) and medium-sized business is characterized by 51-250 employees. Bednárová (2007) is using this sorting too.

Nowadays, very often word used in corporate governance is process. An increasing emphasis is placed on process management which acts new view of an organization and management of 
the company. It is alternative to department or functional arrangement in which a business is divided into unit operations, divisions and departments and each unit has its own agenda and responsibilities. These units tend to creating barriers around in this model (especially communication and information), and the quality of work essential for prosperity of the company suffers (Arisis, 2009). New process direction in organizing of companies is based on the fact that every product (product or service) is a certain sequence of activities- thus the process. That is why the new way of displaying organizational relationships through process (gradual) diagram is adapted. This diagram includes all necessary activities, the connections between them, their sequence and responsible staff. This way of organizing defines activities and employees responsible for their solution. This direction of management is applied mainly in large companies, but it does not mean that it could not be applied in SME as well (Rolínek, 2009).

SME mostly act in small markets or only in one area of the market. Thus they have limited number of products. This will on the other hand bring a number of advantages. The main advantages of small and medium-sized businesses include flexibility to respond to market changes (Harmon, 2007). As an additional benefit, we can state a considerable customer orientation. Closer contact with customers. Minimum number of intermediary component between the workers coming into contact with customers and senior management. Fervor of an entrepreneur and his efforts to develop the company. Great flexibility, which is very important in a fast-changing marketing and others parts of environment.

On the other hand, to the detriment of small and medium-sized companies talk primarily limited resources in the financial, personnel, and last but not least the lack of theoretical knowledge and practical experience of an entrepreneur. After reviewing the above mentioned advantages and disadvantages of small and medium-sized enterprises it is necessary to emphasize that the processes must be applied under these conditions with regard to use of basic above mentioned advantages and aspects of the marked disadvantage must be eliminated or be completely removed (Wagnerová, 2008).

\section{Research Methodology}

The application of process management in SME investigates the Department of Management of the Faculty of Economy within the grant of the University of South Bohemia GAJU 068/2010/S. In this article we will concern on processes and indicators monitored in the research. Data were obtained in a questionnaire survey in 2010. 188 business subjects were analyses on the whole, 11 interviewers took part in data acquiring. Monitored subjects came from 53 different locations (localization according to their zip code), most of them came from České Budějovice (66 subjects with the 37001 zip code), the second area Horažd'ovice (14 with 34101 zip code), the third Klatovy (10 subjects with 33901$)$. The activity structure of the subjects is evident from the following data. The largest proportion consisted of subjects oriented on an engineering production $(30 \%)$. Further, the business were divided on the construction activities (28\%), trade and services (24\%), wood production (12\%) and the last group consists of companies focused on food production (6\%). The average length of participation in the market of all subjects was 17.27 years. Only a quarter of subjects have worked and been on the market for more than 19 years. 11 interviewers were attended on data acquisition. For basic data processing were used commonly used procedures for processing surveys. Procedures commonly used for processing surveys were used for basic data analysis. To get initial ideas of the character of data frequency tables were constructed by one-stage classification, possibly by two-stage classification of PivotTable. 


\section{Marketing and Business}

All 188 subjects monitored some of indicators set out in the framework of selected processes (marketing and trade, financial management and human resources). Present results are concern to indicators with $50 \%$ and higher viewing figures. The results reflect the current situation and future trends according to the meanings of leaders of the SMEs in the South Bohemia region.

Table 1: Indicators monitored in the process of "Marketing and Business" in SMEs reported in\%.

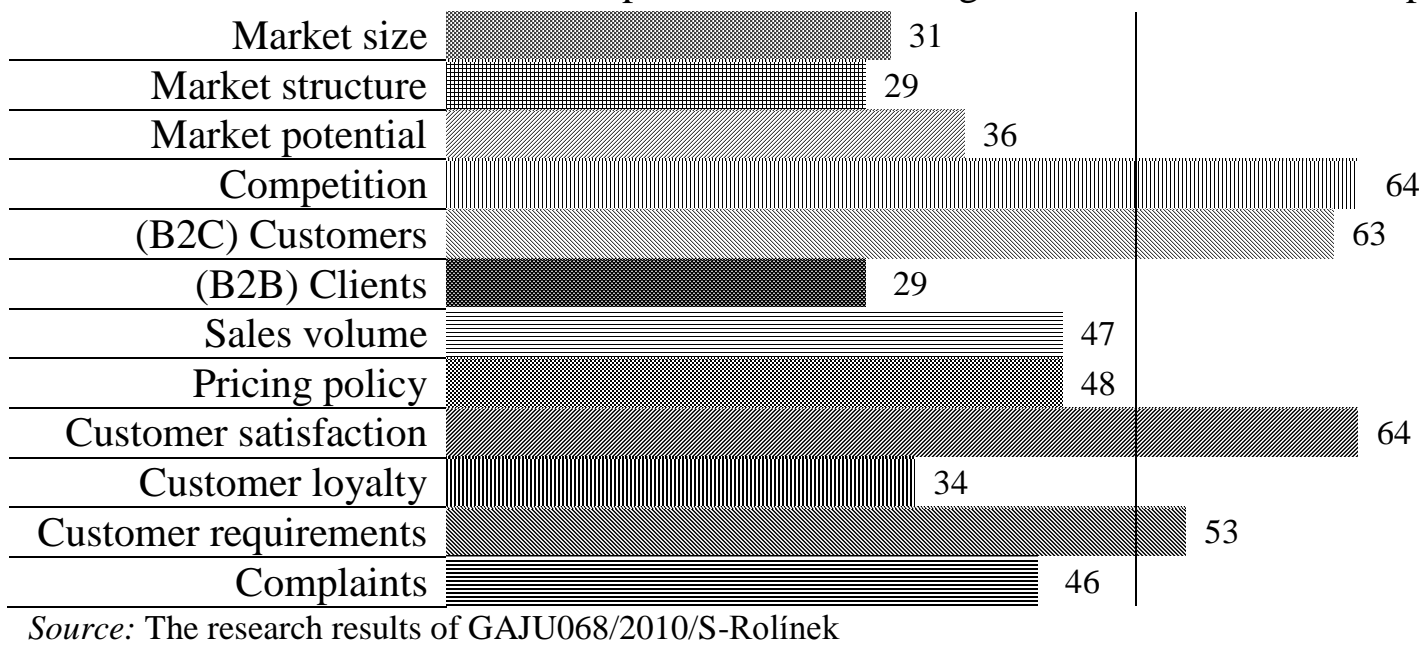

In the process of marketing and business are the following indicators monitored by $50 \%$ and higher viewing, competition (64\%), customers $(63 \%)$, customer satisfaction $(64 \%)$ and customer needs $(53 \%)$. These indicators and their ratings confirm the theory of marketing implemented in small and medium-sized companies and that these companies focus mainly on customers and their satisfaction. Surprising is the low viewership of customer loyalty $34 \%$ and $46 \%$ of complaints where the "complaint procedure" may build a relationship with customers and strengthen their loyalty to the company or brand very well. Furthermore, the results indicate that for small and medium businesses are more important $\mathrm{B} 2 \mathrm{C}$ customers compared to B2B customers, which monitors only $29 \%$ of businesses. 
Table 2: Current status and trends of selected indicators in the process of "Marketing and Business", as perceived by SMEs in the South Bohemian region.

\begin{tabular}{|c|c|c|c|c|}
\hline Competition & current status & $\%$ & trend & $\%$ \\
\hline & very good & 3 & rapidly grow. & 2 \\
\hline & good & 39 & growing & 54 \\
\hline & average & 40 & stagnant & 36 \\
\hline & bad & 16 & decreasing & 6 \\
\hline & very bad & 2 & rapidly decline. & 2 \\
\hline \multirow[t]{6}{*}{ Customers } & current status & $\%$ & trend & $\%$ \\
\hline & very good & 16 & rapidly grow. & 2 \\
\hline & good & 50 & growing & 45 \\
\hline & average & 28 & stagnant & 43 \\
\hline & bad & 6 & decreasing & 10 \\
\hline & very bad & 0 & rapidly decline. & 1 \\
\hline \multirow[t]{6}{*}{ Customer satisfaction } & current status & $\%$ & trend & $\%$ \\
\hline & very good & 41 & rapidly grow. & 14 \\
\hline & good & 50 & growing & 61 \\
\hline & average & 9 & stagnant & 24 \\
\hline & bad & 0 & decreasing & 1 \\
\hline & very bad & 0 & rapidly decline. & 0 \\
\hline \multirow[t]{6}{*}{ Customer requirements } & current status & $\%$ & trend & $\%$ \\
\hline & very good & 17 & rapidly grow. & 5 \\
\hline & good & 66 & growing & 62 \\
\hline & average & 18 & stagnant & 32 \\
\hline & bad & 0 & decreasing & 1 \\
\hline & very bad & 0 & rapidly decline. & 0 \\
\hline
\end{tabular}

Source: The research results of GAJU068/2010/S-Rolínek

For selected indicators was further monitored current status and trend. At present, with the indicator of customer satisfaction were satisfied $91 \%$ of businesses and evaluate it as good or very good. More than half of the companies ( $75 \%$ ) find trend for this indicator to be growing. $83 \%$ of companies characterizes the current situation of needs of customers indicator as good or very good, growing trend $(67 \%)$ of the indicator corresponds with experience and other theories, claiming that customer demands are constantly increasing. Further indicator corresponds to the real market situation, where we are witnesses of still tougher competitive fights, even within the small and medium enterprises. State of competition indicator evaluate $40 \%$ of enterprises as moderate, $16 \%$ as poor and $2 \%$ as very poor. Declining trend within the competition indicator was confirmed by only $8 \%$ of companies, the remaining $92 \%$ of businesses evaluate competition trend as stagnant, growing rapidly or even increasing.

\section{Finance}

In the finance process, there are observed by more than a half of businesses of the sample indicators as profit (90\%), cash flow (58\%), revenues $(81 \%)$ and Wages and salaries $(55 \%)$. These results do not confirm one of the hypotheses that have been set at the beginning of the research. Specifically, the hypothesis that all firms from the sample pursue profit. A further hypothesis that the highest number of indicators with $50 \%$ and higher viewing figures will be in the finance process, even this hypothesis has not been confirmed, the number of indicators in the finance process is equal (4) as the number of indicators in the process of marketing and business. In contrast, in this process there are many indicators (4), which have ratings equal or lower than $20 \%$. 
Table 3: Indicators monitored in the process of "Finance" in SMEs reported in\%.

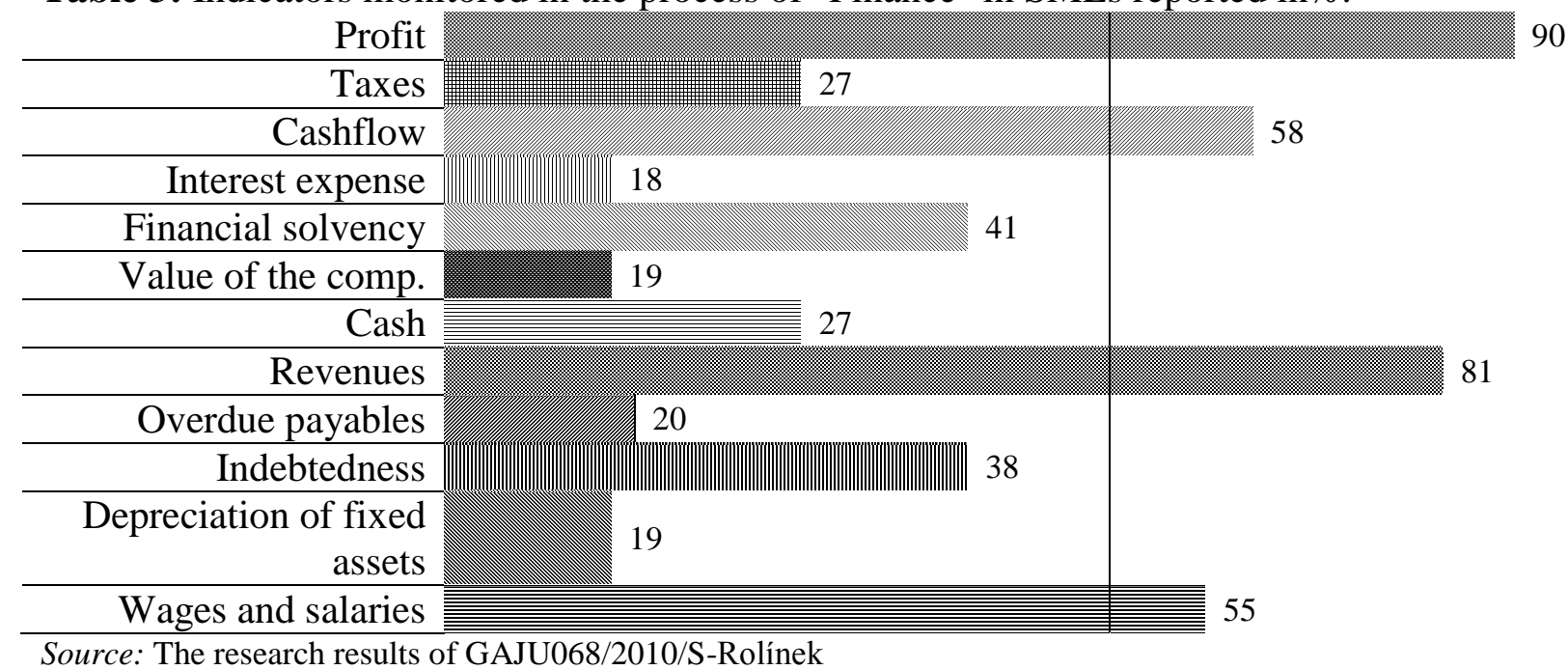

Positive finding is that $58 \%$ subjects of the sample are satisfied with the current situation of profit and at $45 \%$ of businesses there is the increasing profit, declining profit at only $14 \%$ of businesses. With this indicator relates revenues, which reached similar values of measured characteristics, satisfied with the current situation are $63 \%$ of businesses and increasing revenues were confirmed by $57 \%$ of businesses. Wages and salaries grow at $39 \%$ of SMEs and reduce only at $5 \%$ of businesses.

Table 4: Current Status and trends of selected indicators in the framework of the "Finance", as perceived by SMEs in the South Bohemian region.

\begin{tabular}{|c|c|c|c|c|}
\hline Profit & current status & $\%$ & trend & $\%$ \\
\hline & very good & 10 & rapidly grow. & 2 \\
\hline & good & 48 & growing & 43 \\
\hline & average & 29 & stagnant & 41 \\
\hline & bad & 13 & decreasing & 13 \\
\hline & very bad & 1 & rapidly decline. & 1 \\
\hline \multirow[t]{6}{*}{ Revenues } & current status & $\%$ & trend & $\%$ \\
\hline & very good & 14 & rapidly grow. & 2 \\
\hline & good & 49 & growing & 55 \\
\hline & average & 29 & stagnant & 33 \\
\hline & bad & 8 & decreasing & 10 \\
\hline & very bad & 0 & rapidly decline. & 0 \\
\hline \multirow[t]{6}{*}{ Cashflow } & current status & $\%$ & trend & $\%$ \\
\hline & very good & 10 & rapidly grow. & 0 \\
\hline & good & 50 & growing & 42 \\
\hline & average & 33 & stagnant & 50 \\
\hline & bad & 8 & decreasing & 8 \\
\hline & very bad & 0 & rapidly decline. & 0 \\
\hline \multirow[t]{6}{*}{ Wages and salaries } & current status & $\%$ & trend & $\%$ \\
\hline & very good & 1 & rapidly grow. & 2 \\
\hline & good & 44 & growing & 37 \\
\hline & average & 52 & stagnant & 55 \\
\hline & bad & 3 & decreasing & 5 \\
\hline & very bad & 0 & rapidly decline. & 0 \\
\hline
\end{tabular}

Source: The research results of GAJU068/2010/S-Rolínek 


\section{Human Resources}

In the process of HRM indicators are at least $50 \%$ and higher viewing figures (3). Any indicator does not reach higher than $60 \%$ of the ratings, on the other all monitored indicators (excluding fluctuation $-29 \%$ Time to incorporation $-23 \%$ ) are in relatively narrow range of ratings from 41 to $59 \%$. Ratings for this process is the most balanced of all monitored.

Table 5: Indicators monitored in the process of "Human Resources" in SMEs reported in\%.

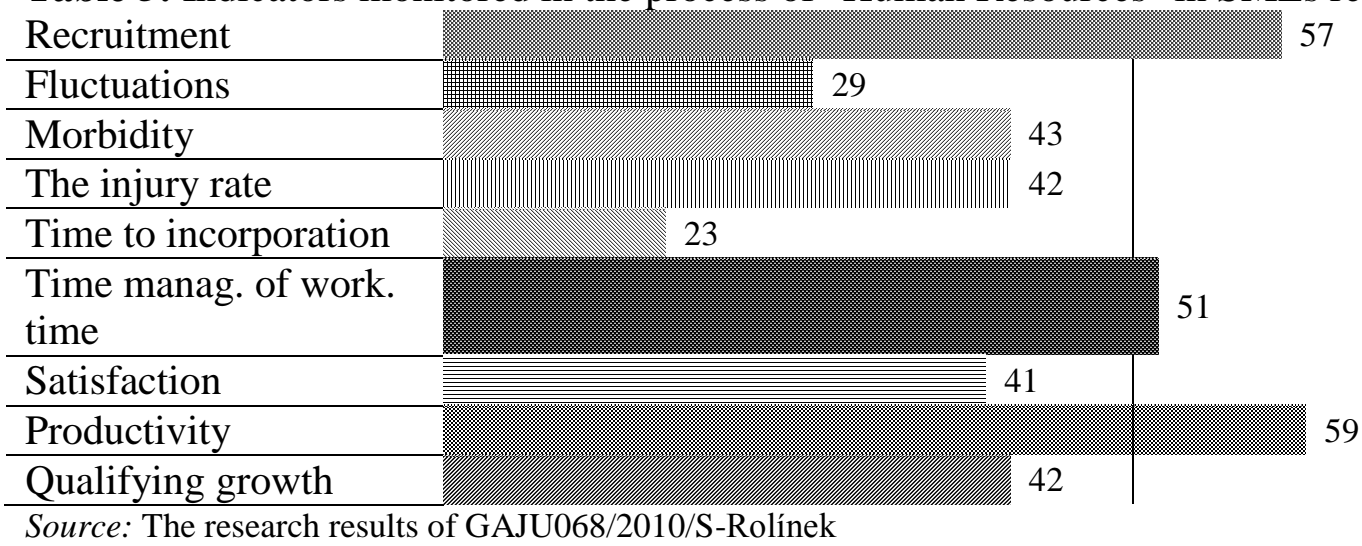

The most viewed indicator is labor productivity (59\%), with this indicator are satisfied $76 \%$ studied firms. This indicator is evaluating as growing by $65 \%$ companies and $32 \%$ companies evaluate it as sluggish. Recruitment is evaluating by absolute majority of businesses as good, despite the fact that recruitment grows only in $38 \%$ of enterprises, in more than half of companies (58\%) is reducing and it is stagnated at $4 \%$ of businesses. These facts only indicate reduced intake of new employees, it does not mean that the companies fire employees. Use of working time $98 \%$ of companies assessed as good or average and in the same number of enterprises is the trend stagnant or growth, only $2 \%$ of companies evaluate using of working time as going worse.

Table 6: Current Status and trends of selected indicators in the process of "Human Resources", as perceived by SMEs in the South Bohemian region.

\begin{tabular}{|c|c|c|c|c|}
\hline Recruitment & current status & $\%$ & trend & $\%$ \\
\hline & very good & 19 & rapidly grow. & 2 \\
\hline & good & 47 & growing & 36 \\
\hline & average & 27 & stagnant & 58 \\
\hline & bad & 5 & decreasing & 4 \\
\hline & very bad & 3 & rapidly decline. & 0 \\
\hline \multirow[t]{6}{*}{ Productivity } & current status & $\%$ & trend & $\%$ \\
\hline & very good & 14 & rapidly grow. & 3 \\
\hline & good & 62 & growing & 62 \\
\hline & average & 21 & stagnant & 32 \\
\hline & bad & 3 & decreasing & 3 \\
\hline & very bad & 0 & rapidly decline. & 0 \\
\hline $\begin{array}{c}\text { Time manag. of working } \\
\text { time }\end{array}$ & current status & $\%$ & trend & $\%$ \\
\hline & very good & 23 & rapidly grow. & 1 \\
\hline & good & 51 & growing & 52 \\
\hline & average & 25 & stagnant & 45 \\
\hline & bad & 2 & decreasing & 2 \\
\hline & very bad & 0 & rapidly decline. & 0 \\
\hline
\end{tabular}

Source: The research results of GAJU068/2010/S-Rolínek 


\section{Conclusion}

The research results present SMEs view on the current situation and future trend in selected process indicators, the results logically replicate the current situation in the Czech Republic, but also throughout Europe, which is characterized by increasing competitive pressure and emphasis on customer care. Process management is by businesses supported by monitoring above mentioned indicators set in the identified business processes. MSEs focus on basic indicators such as profit, sales, competition, customer satisfaction and productivity. The limited resources of MSEs, not only financial, but also human and experience do not allow them to monitor and evaluate other indicators. SMEs usually pursue as is clear from the research results the parameters that are important for the normal operation of the company and fewer indicators which are necessary for future planning and decision making. There is a question of how necessary is this future view for SMEs, where an average length of participation in the market of subjects was 17.27 years.

\section{References}

[1] ARISIS. Procesní ř́zení [on-line]. c. 2009 [cit. 2011-10-18]. Dostupné na World Wide Web: <http://www.arisys.cz/inpage/isrpro3/>.

[2] BEDNÁŘOVÁ, D., 2007: Inovace a klastry v rozvoji regionů. JU, EF Č. Budějovice, 2007. 66 s. ISBN 978-80-7040-952-7. Management Press, Praha 2003. 700 s. ISBN 807261-029-5.

[3] DALÍKOVÁ, P., M. DUSPIVOVÁ a J. VRCHOTA, 2011: Indikátory hodnocení jako klíčové aspekty aplikace procesniho managementu malých a středních podnikì. Acta Universitatis Bohemiae, Meridionales, roč.14/1. ISSN: 1212-3885

[4] HARMON, P., 2007: Business Process Change. Morgan Kaufman Publisher. ISBN 9780-12-374152-3. $549 \mathrm{~s}$.

[5] ROLÍNEK, L. a kol., 2009: Procesní management. Jihočeská univerzita, Ekonomická fakulta. ISBN: 978-80-7394-148-2, $160 \mathrm{~s}$.

[6] VEBER, J. a kol., 2003: Management, základy, prosperita, globalizace. Management Press, Praha 2000. ISBN 80-7241-029-5

[7] WAGNEROVA, I., 2008. Hodnocení a řízení výkonnosti. Prague: Grada Publishing, 117 p. ISBN 978-80-247-2361-7. 